\title{
Relationship between body weight and body condition score with energy content in the carcass of Pelibuey ewes
}

\author{
Gustavo Díaz-López ${ }^{\text {a }}$, Rosario Salazar-Cuytun ${ }^{\text {b }}$ Ricardo García Herrera ${ }^{\text {a }}$, \\ Angel Piñeiro-Vázquez ${ }^{\text {}}$, Fernando Casanova-Lugo ${ }^{c}$, Alfonso J. Chay-Canul ${ }^{\mathrm{a}}$
}

\begin{abstract}
The determination of energy content in the carcass and body of domestic animals by direct method involves very intensive work and it is costly. The aim of this study was to evaluate the relationship between body weight (BW) and body condition score (BCS) with the energy content of muscular and adipose tissues of adult Pelibuey ewes. Twenty two adult non-pregnant, nonlactating ewes of $35.63 \pm 5.03 \mathrm{~kg} \mathrm{BW}$ and $2.47 \pm 0.55 \mathrm{BCS}$ were used. The correlation coefficients ( $\mathrm{r}$ ) of BCS between muscle energy (ME), fat energy (FE) and total energy (TE) were all significant $(P<0.01)$ with values of $0.64,0.66$ and 0.69 , respectively, while for BW between ME, FE and TE they were all significant $(P<0.001)$ with values of $0.90,0.76$ and 0.89 , respectively. The regression equations had high determination coefficients $\left(\mathrm{r}^{2}\right)$ ranging from 0.87 to 0.94 when BCS was used as predictor, while using the BW the $\mathrm{r}^{2}$ ranged from 0.59 to 0.83 . The inclusion of both BW and BCS in multiple regressions improved the prediction from 2 to $7 \%$; nonetheless, the inclusion of BCS only was significant in the equation for TE. The use of BCS and BW in Pelibuey ewes provides a good estimate of the ME, TE and FE of the carcass.

Key words: carcass energy, body condition, body weight, Pelibuey ewes.
\end{abstract}

RESUMEN. La determinación del contenido de energía de la canal y del cuerpo de los animales domésticos por el método directo es laborioso y de alto costo. El objetivo del presente estudio fue evaluar la relación entre el peso vivo (PV) y condición corporal (CC) con el contenido energético del tejido muscular y graso en ovejas Pelibuey. Se utilizaron los datos de 22 ovejas adultas, no gestantes y no lactantes, con PV de 35,63 $\pm 5,03 \mathrm{~kg}$ y CC de 2,48 \pm 0,55. Los coeficientes de correlación (r) entre la CC, energía del músculo (EM), energía de la grasa (EG) y la energía total (ET) fueron significativas $(P<0,001)$, con valores de $0,64,0,66$ y 0,69 , respectivamente, mientras que para el PV y EM, EG y ET fueron estadísticamente significativos $(P<0,001)$, con valores de $0,90,0,76$ y 0,89 , respectivamente. Las ecuaciones de regresión tuvieron un coeficiente de determinación $\left(\mathrm{r}^{2}\right)$, el cual varió de 0,87 a 0,94 cuando se utilizó a la CC como predictor, mientras que el PV presentó un $\mathrm{r}^{2}$ que varió de 0,59 a 0,83. La inclusión del PV y la CC en regresiones múltiples mejoró la predicción alrededor del 2 al 7\%; no obstante, la inclusión de la CC solo fue significativa en la ecuación de ET. El uso de la CC y el PV en ovejas Pelibuey proporciona una buena estimación de la EM, EG, ET de la canal.

Palabras clave: energía de la canal, condición corporal, peso vivo, ovejas Pelibuey.

\section{INTRODUCTION}

Even today, dissection and chemical analysis represent the standard for body composition determination of farm animals (Silva et al 2016). However, such techniques raise several issues (e.g., ethical problems, the impossibility of within animal comparisons and need of large numbers of animals, very intensive labour and high cost) (Chay-Canul et al 2016, Silva et al 2016).

Different methods for determining carcass and body composition of domestic animals have been extensively studied because of their nutritional and economic importance; however, some methods are either limited for use under laboratory conditions, and due to their expensive cost. Additionally, it has established that non-invasive techniques to predict carcass composition of animals in

\footnotetext{
Accepted: 13.01.2017.

aDivision Académica de Ciencias Agropecuarias, Universidad Juárez Autónoma de Tabasco, Tabasco, México.

${ }^{b}$ Facultad de Medicina Veterinaria y Zootecnia, Universidad Autónoma de Yucatán, Yucatán, México; El Colegio de la Frontera Sur (ECOSUR), Ganadería y Ambiente, Chiapas, México.

'Instituto Tecnológico de la Zona Maya, Quintana Roo, México.

*Corresponding author: AJ Chay-Canul; Carretera Villahermosa-Teapa, km 25, CP 86280, Villahermosa, Tabasco, México; ajchc19@yahoo.com. mx, aljuch@hotmail.com
}

vivo are preferred over techniques involving the destruction of the carcass because they are inexpensive and practical (Scholz et al 2015, Silva et al 2016).

Undernutrition in ruminants is associated with loss of body weight (BW) and changes in body and carcass composition and changes in body condition score (BCS) (Sanson et al 1993, NRC 2007), also, it has been established that a common method to assess body energy concentration is to use the BCS (Sanson et al 1993, NRC 2007). BCS has been used as an index of available body energy reserves in ewes (Kenyon et al 2014), moreover, the BW and BCS have been used for the evaluation and prediction of body energy reserves (Sanson et al 1993, Mendizabal et al 2011).

However, in hair sheep breed the BCS and BW changes have not been correlated to change in body and carcass energy content. Therefore, the aim of this study was to evaluate the relationship between BW and BCS with energy content of the muscular and adipose tissues of adult Pelibuey ewes under tropical conditions.

\section{MATERIAL AND METHODS}

The area of study was located at $20^{\circ} 45^{\prime} \mathrm{N}, 89^{\circ} 30^{\prime} \mathrm{W}$; 8 masl, with a climate $\mathrm{AW}_{0}$ (tropical warm sub-humid with 
summer rainfall). The average annual temperature ranges from 26 to $27.8^{\circ} \mathrm{C}$, with an annual rainfall ranging from 940 to $1100 \mathrm{~mm}$ (García 1988).

The study was carried out using the data of twenty two adult, 3-year-old, non-pregnant, non-lactating Pelibuey ewes with body weight (BW) of $35.63 \pm 5.03 \mathrm{~kg}$ and body condition score (BCS) of $2.47 \pm 0.55$. The animals were randomly assigned to four groups. One of these groups $(n=6)$ was slaughtered at the start of experiment for baseline measurements of energy concentration. The remaining ewes were randomly assigned to three groups and were individually housed in metabolic crates, and were fed at three levels of MEI (metabolisable energy intake): Low (L, $\mathrm{n}=5)$, Medium $(\mathrm{M}, \mathrm{n}=6)$ and High $(\mathrm{H}$, $\mathrm{n}=5$ ) for $65 \mathrm{~d}$, to achieve desirable changes in BW and BCS. Levels of feeding were established as proportions of ME energy requirement for maintenance (MEm, 0.426 $\mathrm{MJ} / \mathrm{kg} \mathrm{BW}$. $75 / \mathrm{d}$, AFRC 1993). The basal diet consisted of fresh, chopped Taiwan grass (Pennisetum purpureum). A supplement with a concentrate based on fruit of velvet bean (Mucuna pruriens, $72 \%$ in DM basis), ground corn (25\% DM basis), and cane molasses (3\%DM basis) was offered according to the feeding group. Ten grams of a commercial mineral mixture were given daily to each animal. Grass was offered in equal halves at 08:00 and 15:00 h, supplying $44 \mathrm{~g} \mathrm{DM} / \mathrm{kg} \mathrm{BW}^{0.75} / \mathrm{d}$, and the supplement at a rate of 0,16 and $32 \mathrm{~g} \mathrm{DM} / \mathrm{kg} \mathrm{BW}^{0.75} / \mathrm{d}$ for treatments $\mathrm{L}, \mathrm{M}$ and $\mathrm{H}$ respectively. Feed offered was adjusted every 15 days based on BW of the ewes (for more details of nutrients consumption and feed management of animals see Chay-Canul et al $\left(2011^{\mathrm{a}}\right)$.

The BCS for each ewe was evaluated by two experienced technicians, using a 1-5 scale with 0.5 increments, where BCS 1 represents a thin animal and 5 an obese animal as described by Russel et al (1969).

Ewes were slaughtered using a humanitarian method according to Mexican Official norms (NOM-08-ZOO, NOM-09-ZOO and NOM-033-ZOO) established for slaughter and processing of meat animals. Before slaughter, shrunk BW (SBW) was measured after feed and water were withdrawn during $24 \mathrm{~h}$. Data recorded at slaughter were weights of internal organs and carcass. Internal fat (TIF, internal adipose tissue) was dissected, weighed and grouped as pelvic (around kidneys and pelvic region) and surrounding the alimentary tract (omental and mesenteric fat). Carcass was then split at the dorsal midline in two equal halves, weighed, and chilled at $6^{\circ} \mathrm{C}$ during $24 \mathrm{~h}$. After refrigeration, the left half of the carcass was completely dissected into subcutaneous and intramuscular fat (carcass fat, TCF), muscle, bone and each component weighed separately. Dissected tissues of the left carcass were adjusted as whole carcass.

A proportional sample $(1 \mathrm{~kg})$ was taken from each animal of the muscle and adipose tissue of the carcass, ground with a screw grinder (Torrey, Co) through a 4 $\mathrm{mm}$ mesh. Tissue samples were freeze dried to determine water content (Labconco, Co., USA). The dry samples were reground in a hammer mill and gross energy was determined using an adiabatic bomb calorimeter (Parr, USA) according the AOAC (1980).

A descriptive statistical analysis for BW, BCS and muscle energy (ME), fat energy (FE) and total energy (TE, sum of energy of muscle and fat) was performed using the PROC MEANS of SAS (SAS Inst. Inc., Cary, NC, 2010). Correlation coefficients among variables were estimated using the procedure PROC CORR of SAS (SAS Ver. 9.3, 2010). Regressions were developed with PROC REG of SAS (SAS Ver. 9.3, 2010). The option STEPWISE and Mallow's Cp were used in the SELECTION statement to select the variables included in the model. The accuracy of the models was evaluated by the determination coefficient $\left(\mathrm{R}^{2}\right)$ and means square error (MSE).

\section{RESULTS}

The means $( \pm \mathrm{SD})$, minimum and maximum values of BW, BCS, ME, FE and TE of adult Pelibuey ewes are shown in table 1 . The correlation coefficients (r) of BCS between ME, FE and TE were all significant $(P<0.01)$ with values of $0.64,0.66$ and 0.69 respectively. For BW between ME, FE and TE were all significant $(P<0.001)$ with values of $0.90,0.76$ and 0.89 respectively (table 2 ).

In the table 3 , are showed the means square of carcass energy content in each BCS grades. The regression equations had high determination coefficients $\left(r^{2}\right)$ that ranged from 0.87 for $\mathrm{FE}$ and 0.94 for $\mathrm{ME}(\mathrm{RSD}=15.70$ and 17.95 respectively) when BCS was used as predictor, while using the BW the $\mathrm{r}^{2}$ ranged from 0.59 for $\mathrm{FE}$ and 0.83 for $\mathrm{ME}(\mathrm{RSD}=13.09$ and 10.01 respectively $)$. The equation intercept of the relationship between BCS and ME, FE and TE in the carcass of Pelibuey ewes, was no significant, so, were fitted a linear regressions through the origin (table 4). The inclusion of both BCS and BW as independent variables in a multiple regression improved the prediction around from $2 \%$ to $7 \%$ for $\mathrm{ME}$ and $\mathrm{FE}$, respectively; nonetheless, the inclusion of BCS only was significant in the equation for TE (table 4).

\section{DISCUSSION}

Body energy content, represented by fat and muscle body content as well as body composition, are important determinants of the reproductive performance and carcass quality in livestock (Vilar-Martinez et al 2009). However, there is a lack of information about the efficiency of use of mobilized tissues energy for maintenance as well for other functions (NRC 2007). The ruminants are often subjected to periods of restricted nutrient intake, during which time body tissues are mobilized to maintain vital life functions. Subsequently, nutrient intake is elevated to replenish body energy and perhaps protein stores necessary for production (Ngwa et al 2007a). 
Table 1. Mean, minimum and maximum values of variables in adult Pelibuey ewes.

\begin{tabular}{lcccccc}
\hline Variable & $\mathrm{n}$ & Mean & Maximum & Minimum & SD & CV $(\%)$ \\
\hline BCS & 22 & 2.48 & 3.50 & 1.50 & 0.55 & 22.00 \\
BW (kg) & 22 & 35.63 & 48.75 & 29.00 & 5.03 & 14.11 \\
ME (MJ) & 22 & 69.58 & 147.05 & 37.34 & 23.53 & 33,82 \\
FE (MJ) & 22 & 38.32 & 76.58 & 10.50 & 19.99 & 52.18 \\
TE (MJ) & 22 & 107.90 & 218.73 & 48.30 & 41.15 & 38.14 \\
\hline
\end{tabular}

SD: standard deviation; CV: coefficient of variation; BCS: body condition score; BW: body weight; ME: muscle energy; FE: fat energy; TE: total energy.

Table 2. Correlation coefficients of variables to predict the carcass energy content in Pelibuey ewes.

\begin{tabular}{|c|c|c|c|c|}
\hline Variable & BW & BCS & $\mathrm{ME}$ & $\mathrm{FE}$ \\
\hline BCS & $0.58 * *$ & & & \\
\hline $\mathrm{ME}$ & $0.90 * * *$ & $0.64 * * *$ & & \\
\hline FE & $0.76 * * *$ & $0.66^{* *}$ & $0.78 * * *$ & \\
\hline $\mathrm{TE}$ & $0.89 * * *$ & $0.69 * *$ & $0.95 * * *$ & $0.93 * * *$ \\
\hline
\end{tabular}

$* * * P<0.0001 ; * * P<0.001 ; * P<0.05 ;$ ns: no significant; BCS: body condition score; BW: body weight; ME: muscle energy; FE: fat energy; TE: total energy

Table 3. Least square means $( \pm \mathrm{SE})$ for energy content in Pelibuey in each BCS grades.

\begin{tabular}{|c|c|c|c|c|c|c|}
\hline & \multicolumn{5}{|c|}{$\mathrm{BCS}$} & \multirow{2}{*}{ P-value } \\
\hline & 1.5 & 2.0 & 2.5 & 3.0 & 3.5 & \\
\hline ME & $59.85^{\mathrm{a}} \pm 5.04$ & $58.08^{\mathrm{a}} \pm 6.07$ & $69.63^{\mathrm{a}} \pm 2.29$ & $87.90^{b} \pm 5.28$ & $67.8^{\mathrm{a}} \pm 5.83$ & $<0.0001$ \\
\hline FE & $22.69^{\mathrm{a}} \pm 7.77$ & $28.71^{\mathrm{a}} \pm 9.36$ & $42.75^{b} \pm 3.53$ & $37.92^{\mathrm{a}} \pm 8.14$ & $45.35^{\mathrm{ab}} \pm 8.98$ & 0.0006 \\
\hline $\mathrm{TE}$ & $82.55^{\mathrm{a}} \pm 10.73$ & $86.79^{a} \pm 12.92$ & $112.39^{b} \pm 4.88$ & $125.83^{\mathrm{b}} \pm 11.24$ & $113.25^{\mathrm{ab}_{ \pm}} 12.40$ & $<0.0001$ \\
\hline
\end{tabular}

SE: Standard Error; BCS: body condition score; ME: muscle energy (MJ); FE (MJ): fat energy (MJ); TE: total energy (MJ).

Table 4. Regression equations to estimate the energy content of the carcass $(Y)$ in adult Pelibuey using the BCS and BW $(X)$.

\begin{tabular}{|c|c|c|c|c|c|c|c|c|c|}
\hline $\mathrm{N}$ & $\mathrm{Eq}^{\mathrm{c}}$ & & $\mathrm{a} \pm \mathrm{SE}$ & $\mathrm{BCS} \pm \mathrm{SE}$ & $\mathrm{BW} \pm \mathrm{SE}$ & $\mathrm{R}^{2}$ & MSE & RSD & P-value \\
\hline 22 & 1 & $\mathrm{ME}$ & & $28.08 * * * \pm 1.51$ & & 0.94 & 322.28 & 17.95 & $<0.0001$ \\
\hline 22 & 2 & & $-82.14 * * * \pm 15.63$ & & $4.26 * * * \pm 0.43$ & 0.83 & 100.19 & 10.01 & $<0.0001$ \\
\hline 22 & 3 & $\mathrm{FE}$ & & $15.86 * * * \pm 1.32$ & & 0.87 & 246.70 & 15.70 & $<0.0001$ \\
\hline 22 & 4 & & $-70.71 * * * \pm 20.43$ & & $3.06 * * * \pm 0.57$ & 0.59 & 171.25 & 13.09 & $<0.0001$ \\
\hline 22 & 5 & TE & & $43.94 * * * \pm 2.53$ & & 0.93 & 905.35 & 30.09 & $<0.0001$ \\
\hline 22 & 6 & & $-152.85 * * * \pm 29.48$ & & $7.32 * * * \pm 0.82$ & 0.80 & 356.64 & 18.89 & $<0.0001$ \\
\hline \multicolumn{10}{|c|}{ Multiple regression } \\
\hline 22 & 7 & ME & $-83.59 * * * \pm 15.17$ & $7.28^{\mathrm{ns}} \pm 4.80$ & $3.79 * * * \pm 0.52$ & 0.85 & 94.11 & 9.70 & $<0.0001$ \\
\hline 22 & 8 & $\mathrm{FE}$ & $-73.04 * * \pm 19.21$ & $11.70^{\mathrm{ns}} \pm 6.09$ & $2.31 * * \pm 0.66$ & 0.66 & 150.95 & 12.28 & $<0.0001$ \\
\hline 22 & 9 & $\mathrm{TE}$ & $-156.63 * * * \pm 27.01$ & $18.98 * \pm 8.56$ & $6.10 * * * \pm 0.92$ & 0.84 & 298.24 & 17.26 & $<0.0001$ \\
\hline
\end{tabular}

$\mathrm{R}^{2}$ : coefficient of determination; MSE: Mean Square Error; RSD: Residual Standard Deviation; SE: Standard Error; BCS: body condition score; BW: body weight (kg); ME: muscle energy (MJ); FE (MJ): fat energy (MJ); TE: total energy (MJ).

cNumber of equation. $* P<0.05 ; * * P<0.001 ; * * * P<0.0001$, ns: non significant. 
There are different methods for estimating body energy reserves, some of them under controlled conditions, however, $\mathrm{BW}$ and BCS are preferred under practical conditions. The BCS has been the preferred method used for estimating energy body reserves and nutritional status in different breeds of ewes (Chay-Canul et al 2011 ${ }^{\mathrm{b}}$, Kenyon et al 2014) and can be useful for determining feed needs or energy mobilized during specific changes of BW in goats (Ngwa et al $2007^{\mathrm{b}}$ ).

In cows, a method to estimate energy balance (EB) using daily BW measurements combined with frequent body condition score (BCS) measurements has recently been developed (Thorup et al 2012, 2013). Moreover, Thorup et al (2012) reported that the EB of individual cows can be estimated from body reserve changes using $\mathrm{BW}$ and BCS.

In the present study, the carcass energy content variation was better explained for the BCS compared to BW. Similar results were obtained for Sanson et al (1993) who found that BCS was highly related to carcass lipids in ewes $\left(r^{2}=0.90\right)$. On the other hand, Frutos et al (1997) reported that the BCS was not accurate for estimating body composition in mature Churra ewes. Recently, ChayCanul et al $\left(2011^{\mathrm{b}}\right)$ reported that the BW was superior to BCS for predicting the main body fat depots in Pelibuey ewes. The body energy content is mainly influenced by animal breed, nutritional management and physiological state, therefore, for adequate evaluation it is important to consider these factors in further studies, independently of the regions of the world.

Body composition predictions derived from the equations of Sanson et al (1993) and Cannas et al (2004) are presented by the NRC (2007), concluding that the considerable differences found for those authors are most likely functions of the specific breed and the variable relationships between body fat and BCS and the lack of a broader data set to develop predictive equations.

In growing male hair sheep of 12 to $45 \mathrm{~kg}$, Chay-Canul et al (2016) found values of energy content ranging from 5.10 to $12.47 \mathrm{MJ} / \mathrm{kg} \mathrm{EBW}$; and fitted an equation to predict the energy content in EBW= Energy $(\mathrm{MJ} / \mathrm{kg} \mathrm{EBW})$ $=3.322( \pm 1.108 * * *)+0.449( \pm 0.098 * * *) \times \mathrm{EBW}-0.006$ $( \pm 0.002 * * *) \times \mathrm{EBW}^{2}\left(\mathrm{R}^{2}=0.71 ; \mathrm{MSE}=0.976 ; \mathrm{RSD}=0.988\right.$; $P=<0.0001$ and $n=39)$.

Since there is no information about carcass energy concentration in ewes, information of growing lambs is used in part of the discussion. Gross energy concentration values of the carcass ewe in this work were higher than those reported by Cantón et al (2009) for growing hair lambs of 30 and $35 \mathrm{~kg}$ live weight, they estimated values for carcass energy content (using only the weight of muscle and adipose tissues in the carcass) between 53.8 and 88.0 MJ. Further studies are needed to determine the whole body composition of Pelibuey sheep and to evaluate alternative methods for their prediction in live animals considering animal breed, nutritional management and physiological state.

It is concluded that the BCS showed a better estimation of the ME, FE, and TE of the carcass than BW in Pelibuey ewes. Future studies should use the BCS as the preferred tool for estimating the body energy content in this hair sheep breed.

\section{REFERENCES}

AFRC, Agricultural and Food Research Council. 1993. Technical committee on responses to nutrients. Energy and protein requirements of ruminants. CAB International, Wallingford, UK.

AOAC, Association of Official Analytical Chemists. 1980. Official Methods of Analysis. 15 $5^{\text {th }}$ ed. Washington D.C., USA.

Cannas A, Tedeschi LO, Fox DG, Pell AN, Van Soest PJ. 2004. A mechanistic model for predicting the nutrient requirements and feed biological values for sheep. J Anim Sci 82, 149-169.

Cantón CJG, Bores QR, Baeza RJ, Quintal FJ, Santos RR, et al. 2009. Energy Retention of F1 Pelibuey lambs with breeds for meat production. J Anim Vet Adv 8, 2655-2661.

Chay-Canul AJ, Ayala-Burgos AJ, Kú-Vera JC, Magaña-Monforte JG, Ferrell CL. 2011 ${ }^{\mathrm{a}}$. Metabolizable energy intake and changes in body weight and body condition of Pelibuey ewes fed three levels of roughage diets under tropical conditions. Trop Subtrop Agroecosys 14, 777-786.

Chay-Canul AJ, Ayala-Burgos AJ, Kú-Vera JC, Magaña-Monforte JG, et al. $2011^{\mathrm{b}}$. The effects of metabolizable energy intake on body fat depots of adult Pelibuey ewes fed roughage diets under tropical conditions. Trop Anim Health Prod 43, 929-936.

Chay-Canul AJ, Magaña-Monforte JG, Chizzotti ML, Piñeiro-Vázquez AT, Canul-Solís JR, et al. 2016. Energy requirements of hair sheep in the tropical regions of Latin America. Review. Rev Mex Cien Pecu 7, 105-125.

Frutos P, Mantecon AR, Giraldez FJ. 1997. Relationship of body condition score and live weight with body composition in mature Churra ewes. Anim Sci 64, 447-452.

García E.1988. Modificaciones del sistema de clasificación climática de Köppen (para adaptarlo a las condiciones de la República Mexicana). Instituto de Geografía, UNAM, México, DF.

Kenyon PR, Maloney SK, Blache D. 2014. Review of sheep body condition score in relation to production characteristics. New Zeal J Agr Res 57, 38-64.

Mendizabal JA, Delfa R, Arana A, Purroy A. 2011. Body condition score and fat mobilization as management tools for goats on native pastures. Small Rumin Res 98, 121-197.

Ngwa AT, Dawson LJ, Puchala R, Detweiler G, Merkel RC, et al. $2007^{\mathrm{a}}$. Urea space and body condition score to predict body composition of meat goats. Small Rumin Res 73, 27-36.

Ngwa AT, Dawson LJ, Puchala R, Detweiler G, Merkel RC, et al. $2007^{\mathrm{b}}$. Effect of initial body condition of Boer $\times$ Spanish yearling goat wethers and level of nutrient intake on body composition. Small Rumin Res 73, 13-26.

NRC, National Research Council. 2007. Nutrient requirements of small ruminants: sheep, goats, cervids, and new world camelids. $6^{\text {th }}$ ed. National Academy Press, Washington, USA.

Russel AJF, Doney JM, Gunn RG. 1969. Subjective assessment of body fat in live sheep. J Agr Sci 72, 451-454.

Sanson DW, West TR, Tatman WR, Riley ML, Judkins BM, et al. 1993. Relationship of body composition of mature ewes with condition score and body weight. J Anim Sci 71, 1112-1116.

SAS, Statistical Analysis System. 2010. SAS version 9.3. SAS Institute Inc., Cary, NC, USA.

Scholz AM, Bünger L, Kongsro J, Baulain U, Mitchell AD. 2015. Non-invasive methods for the determination of body and carcass 
composition in livestock: dual-energy X-ray absorptiometry, computed tomography, magnetic resonance imaging and ultrasound: invited review. Animal 9, 1250-1264.

Silva SR, Afonso J, Guedes CM, Gomes MJ, Santos VA, et al. 2016. Ewe whole body composition predicted in vivo by real-time ultrasonography and image analysis. Small Rumin Res 136, 173-178.
Thorup VM, Edwards D, Friggens NC. 2012. On-farm estimation of energy balance in dairy cows using only frequent body weight measurements and body condition score. J Dairy Sci 95, 1784-1793.

Thorup VM, Højsgaard S, Weisbjerg MR, Friggens NC. 2013. Energy balance of individual cows can be estimated in real-time on farm using frequent liveweight measures even in the absence of body condition score. Animal 7, 1631-1639. 
